\title{
Alternatives to Corporal Punishment Gaining Momentum in U.S. Schools
}

\author{
Cynthia Northington Purdie \\ William Paterson University of New Jersey, USA
}

\begin{abstract}
The practice of corporal punishment is on the wane in the United States public schools. The Internet has provided a national window to school discipline practices. The reports and ramifications of the use of paddles, sticks and physical discomfort on students in order to enforce school rules are sobering. This is the result of the increased scrutiny under to which teachers and administrators have been subject due to this often controversial practice. Although corporal punishment is still legal in twenty of the fifty states, there has been increased interest in alternative (top down) methods of classroom management. Some states have abolished corporal punishment and reinstated it due to the perceived absence of alternatives. Realistic alternatives can be proposed and demonstrated to be effective to states that still legally practice paddling. Top-down classroom management alternatives offer humane, organized guidelines to students. They teach appropriate behaviors rather than merely penalizing negative behaviors.
\end{abstract}

\section{Introduction}

According to data released in March 2008 by the U.S. Office of Civil Rights, corporal punishment was administered legally to 223,190 public school children. This is 49,838 less students paddled that the previous year and 118,848 students less than reported at the turn of the 21 century. [1] Websites such as the now defunct Google Video, YouTube and others have given students the opportunity to post classroom scenarios as they occur (often to the embarrassment of administrators). As parents view the behavior management practices online first hand, demands for change have become difficult to ignore. Although the numbers reflect a shift in discipline philosophies and practices on a national scale, the problem still exists. In the 20 states in which this practice remains legal, strict guidelines are in place to protect student, teacher and administrator from cruelty and litigation. The use (and frequency of use) of a paddle, stick or physical hardship is clearly spelled out in school handbooks and web sites. Despite often strict guidelines for the use of corporal punishment, lawsuits are regularly filed by the families of its recipients due to excesses use. In response to increased national scrutiny, school administrators report that discipline policies and procedures are adhered to before, during and after each instance [2].

\section{The Arguments}

The argument in favor of school corporal punishment is that it signals a respect for authority. It is also stated that when fear is not a factor, there is no reason for children to comply with rules and regulations. Advocates point to the Internet as a defense of the practice. Public domain videos allow viewers to see first-hand the situations that warrant extreme disciplinary measures. It is perhaps for this reason that states like West Virginia for example, banned corporal punishment in the early 1990's and reestablished shortly thereafter. Spanking, it is argued, is a return to traditional values. [3] However, recent studies have shown that in states where students are spanked there have been more instances of school violence (included homicide and weaponsrelated violent death). This implies a disregard for a societal authority that prohibits violent behavior. There also appear to be more school shootings in states that have legal corporal punishment than in states that have banned it. [4, 5] Students who are empowered to bring weapons to school and utilize them on their peers are not impeded by fear of consequences. It is therefore argued that the same applies to students are not deterred by the fear of being paddled.

As information about this practice and its ramifications continues to reach the World Wide Web, calls for its abolishment have become more vociferous. Even primitively uploaded videos posted in the 1990 have had an effect on public perception. For example, eight states banned corporal punishment in the schools. In the millennia, three more states (Delaware, Pennsylvania and Ohio) have signed legislation as well. When a state terminates the practice of spanking, there is the necessity of replacing it with a model in which practitioners accustomed to traditional practices can invest.

Contemporary approaches emphasize a classroom management focus rather than discipline. Top down classroom management approaches provide schools that previously relied on corporal punishment a comfortable transition to a discipline model that emphasizes the authority of the teacher and administration without inflicting pain humiliation on 
a student. Classroom management is therefore achieved without completely altering a school's disciplinary conceptual framework.

\section{Alternatives}

Lee Canter's assertive discipline program for example, is a viable alternative in that like corporal punishment, it places the teacher firmly in charge on the classroom. Rules, rewards and punishments are determined by the teacher. Despite its humanity and authoritative philosophy, it is basically a top down approach that focuses on students who comply with school rules while providing gradations of negative reinforcement for repeat classroom offenders.

There is evidence that behavior modification programs and applied behavior analysis for extreme disciplinary cases can also provide viable alternatives to the traditional disciplinary model.

In view of the trends, the top down discipline focus is a realistic first step for states that abandon corporal punishment. Imposing millennial styles of student centered classroom management before schools are ready can be a set up for failure and a return to traditional discipline. States that have never sanctioned corporal punishment for example, advocate contemporary classroom management programs which feature online teacher support such as cooperative discipline, positive behavior support, and Forrest Gathercoal's, Judicious Discipline. These programs place the onus of behavior, rewards and consequences on the students and community. Teachers, administrators and students work together cooperatively to conceptualize discipline in the educational environment.

\section{Conclusions}

Although corporal punishment offers teachers a quick and seemingly easy solution to challenging classroom behaviors, it disregards the long-term effects of the procedure on children. It flies in the face of modern curricular emphases on cooperative teaching and learning. The Internet has irrevocably brought the practice to the attention of the public. It contradicts universally condoned messages of prosocial behavior which resonate to character education programs nationwide. It fails to take into acknowledge the accountability that surveillance cameras and posted videos can demand of all school personnel. The American Civil Liberties Union points out that it teaches students to correlate the concept of discipline with violence which perpetuates a culture of violent behaviors. [6] Research continues to evidence the alternatives to this practice as humane, cost effective, research based, and successful when implemented consistently.

\section{References}

[1] U.S. Department of Education. Office of Civil Rights. (2007) 2006 Civil Rights Data Collection. ED 102, Washington, D.C.: U.S. Government Printing Office.

[2] Workman, J. E.; Freeburg, E. W.; Lentz-Hees, E.S. (2004). Sanctions Connected to Dress Code Violations in Secondary School Handbooks. Journal of Family and Consumer Sciences. 96(4), 40-46.

[3] Northington, C. (2007). The use of corporal punishment on minorities in public schools. In Brown, M. C. (Ed.) Still not equal: Expanding educational opportunity in society. New York: Peter Lang.

[4] Arcus, D. (2002) School shooting fatalities and school corporal punishment: A look at the states. Aggressive Behavior 28(3), 173 - 183.

[5] Dinkes, R., Cataldi, E.F., Kena, G., and Baum, K. (2006). Indicators of School Crime and Safety: 2006 (NCES 2007-003/NCJ 214262). U.S. Departments of Education and Justice. Washington, DC: U.S. Government Printing Office.

[6] American Civil Liberties Union (2009). Executive Summary: A Violent Education Corporal Punishment of Children in U.S. Public Schools. Human Rights Watch. www.hrw.org. 